\title{
The effects of the aeroball on plantar pressure during isometric hip contractions
}

\author{
Kyungock Yi ${ }^{*}$, Haelee Moon, Namjeong Son, Jaewon Choi, Haeryoung Won, Kyungsun Kim, Chanmi Kim, Jihee Yi, \\ Hwalee Kim \\ From 4th Congress of the International Foot and Ankle Biomechanics (i-FAB) Community \\ Busan, Korea. 8-11 April 2014
}

Many female college students in South Corea suffer from postural problems and deformities in their lower extremities. In particular, many females exhibit knee valgus or varus. These problems can arise from a variety of causes, from the use of elevated heels, to years of carrying heavy backpacks, and muscle imbalance. There are many different types of exercises to address these problems, but isometric hip contractions are a simple movement that can be done anywhere at any time. This study tested whether foot pressure variables of isometric hip contractions could be improved through the use of an aeroball in order to correct knee deformities.

The purpose of this study was to evaluate the effects of the aeroball on plantar pressure during isometric hip contractions. Subjects for this study were 39 female college students. Subjects' plantar pressure was gauged with a Zebris (Germany) pressure plate while they performed 30 second isometric hip contractions with and without an aeroball (maker, diameter). Independent variables for the study were isometric hip contractions with and without the aeroball. Dependent variables were plantar pressure variables, such as length of $x$ and $y$ axis, path area, path length, and average velocity. All dependent variables were significantly higher with the aeroball.

The increased length of the $\mathrm{x}$ and $\mathrm{y}$ axis, and the larger path area, and path length all demonstrate greater movement during contractions. Thus, with the aeroball, subjects pushed their hips forward more with greater exterior rotation at the thigh, resulting in greater movement of pressure at the feet. In addition, the higher velocity for the aeroball demonstrates that subjects contracted their muscles more forcefully during the 30 -second contraction interval.

In conclusion, pressure plate analysis revealed that isometric hip contractions were more effective with an aeroball. Future studies will build upon these results to evaluate the corrective effects of isometric hip contractions, especially on knee varus and valgus. Furthermore additional studies will investigate the relationship between diminished muscle function in the inner thighs, hips, and posterior chain, and postural problems.

Table 1 The differences in pressure variables according to aeroball usage

\begin{tabular}{|c|c|c|c|c|c|}
\hline dependent variable & $\mathrm{N}$ & $\operatorname{Mean}( \pm S D)$ & $\begin{array}{l}\text { mean } \\
\text { diff. }\end{array}$ & $t$ & $P$ \\
\hline wob_Length_of_x_axis & 39 & $8.79( \pm 2.28)$ & -1.49 & -3.680 & $.001^{* *}$ \\
\hline$\underline{\text { aeroball_Length_of_x_axis }}$ & & $10.27( \pm 2.62)$ & & & \\
\hline wobl_Length_of_y_axis & 39 & $15.15( \pm 6.90)$ & -2.46 & -2.130 & $.040^{*}$ \\
\hline aeroball_Length_of_y_axis & & $17.61( \pm 6.06)$ & & & \\
\hline wob_Path area & 39 & $\begin{array}{l}111.77 \\
( \pm 73.44)\end{array}$ & -36.32 & -2.619 & $.013^{*}$ \\
\hline aeroball_Path area & & $\begin{array}{l}148.09 \\
( \pm 77.24)\end{array}$ & & & \\
\hline wob_Path_length & 39 & $\begin{array}{l}297.01 \\
( \pm 108.37)\end{array}$ & -83.05 & -3.804 & $.001^{* *}$ \\
\hline aeroball_Path_length & & $\begin{array}{l}380.07 \\
( \pm 150.65)\end{array}$ & & & \\
\hline wob_Average_Velocity & 39 & $10.09( \pm 3.67)$ & -2.82 & -3.803 & $.001^{* *}$ \\
\hline aeroball_Average_Velocity & & $12.91( \pm 5.12)$ & & & \\
\hline
\end{tabular}

${ }^{*} \mathrm{p}<.05,{ }^{* *} \mathrm{p}<.01$

wob; without ball

* Correspondence: yikok@ewha.ac.kr

Division of Human Movement Studies, College of Health Science, Ewha

Womans University 


\section{References}

1. Krackow KA: The Technique of Total Knee Arthroplasty. St. Louis; C.V. Mosby Company; 1990.

2. Chao EY, Neluheni EV, Hsu RW, Paley D: Biomechanics of alignment. Orthop Clin N Am 1994, 25:379-86.

doi:10.1186/1757-1146-7-S1-A103

Cite this article as: $Y i$ et al:: The effects of the aeroball on plantar pressure during isometric hip contractions. Journal of Foot and Ankle Research 2014 7(Suppl 1):A103.

Submit your next manuscript to BioMed Central and take full advantage of:

- Convenient online submission

- Thorough peer review

- No space constraints or color figure charges

- Immediate publication on acceptance

- Inclusion in PubMed, CAS, Scopus and Google Scholar

- Research which is freely available for redistribution

Submit your manuscript at www.biomedcentral.com/submit
() Biomed Central 